Discussion Paper No. 11-019

\title{
Gender Differences in Business Success of German Start-up Firms
}

Sandra Gottschalk and Michaela Niefert

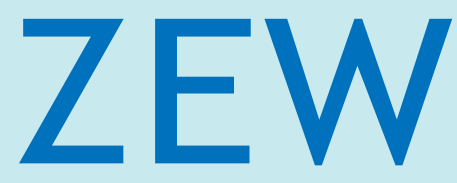

Zentrum für Europäische Wirtschaftsforschung $\mathrm{GmbH}$

Centre for European

Economic Research 
Discussion Paper No. 11-019

\title{
Gender Differences in Business Success of German Start-up Firms
}

\author{
Sandra Gottschalk and Michaela Niefert
}

Download this ZEW Discussion Paper from our ftp server:

ftp://ftp.zew.de/pub/zew-docs/dp/dp11019.pdf

Die Discussion Papers dienen einer möglichst schnellen Verbreitung von neueren Forschungsarbeiten des ZEW. Die Beiträge liegen in alleiniger Verantwortung der Autoren und stellen nicht notwendigerweise die Meinung des ZEW dar.

Discussion Papers are intended to make results of ZEW research promptly available to other economists in order to encourage discussion and suggestions for revisions. The authors are solely responsible for the contents which do not necessarily represent the opinion of the ZEW. 


\section{Non-Technical Summary}

Many studies found that women-owned firms underperform when comparing performance indicators at an aggregate level. The performance gap might be attributed to gender differences in personal and firm characteristics affecting performance. However, previous studies were not able to entirely explain female underperformance in this way. There are two theoretical perspectives on the causes of female underperformance. Liberal feminist theory suggests that women lack access to relevant resources like education and business experience or financial capital. Social feminist theory suggests that women have different attitudes and values and, consequently, adopt a different approach to business.

This paper shall contribute to a better understanding of the causes of female underperformance using performance indicators related to size, growth and profitability. We analyze whether gender differences in observable characteristics like education, experience, team size, entrepreneurial motivation and industry choice explain differences in performance and how large the impact is. We use data from the KfW/ZEW Start-Up Panel and track the performance of about 4,700 German start-up firms over up to four years after foundation. Sales, two measures of employment growth, and return on sales are used as performance indicators.

We find that female-founded firms perform worse for all indicators. At the same time, there are significant gender differences in many of the characteristics observed. Compared to male entrepreneurs, female entrepreneurs have a lower level of formal education, less professional experience, are part of smaller start-up teams, are more often driven by necessity, and are overrepresented in the retail and service industries and in lower-tech industries in general. These differences can explain parts of female entrepreneurial underperformance, but their contribution to the performance gap depends largely on the performance indicator considered.

Our results do not provide clear evidence for either liberal or social feminist theory. As to liberal feminist theory, we find that gender differences in founders' resources (human capital, business partners) partly explain the performance gaps in growth and sales. But there is also evidence that the profitability gap becomes even larger when accounting for gender differences in specific resources like the number of team partners and entrepreneurial experience. As to social feminist theory, the gap in profitability itself speaks against the theory's implication that female entrepreneurs are as efficient managers as male entrepreneurs. We do not find evidence for gender differences in profit orientation but find that female entrepreneurs are less growth-oriented.

Unfortunately, we lack information on the time resources available to male and female entrepreneurs. Thus we are unable to test the hypothesis that female entrepreneurs underperform because they are more strained by domestic responsibilities. Moreover, we lack information on personal traits like risk attitude and self-efficacy which may also affect entrepreneurial performance. 


\section{Das Wichtigste in Kürze}

Empirische Untersuchungen haben gezeigt, dass Unternehmen, die von Frauen gegründet werden, hinsichtlich einer Reihe von Erfolgsindikatoren schlechter abschneiden als von Männern gegründete Unternehmen. Die Performancelücke könnte auf geschlechtsspezifische Unterschiede in den persönlichen und unternehmensbezogenen Merkmalen, die Einfluss auf den Unternehmenserfolg haben, zurückzuführen sein. Bisherige Studien konnten die schlechtere Performance der Unternehmen von Frauen dadurch jedoch nicht vollständig erklären. Es gibt zwei theoretische Ansätze zur Erklärung der Performancelücke. Der erste Ansatz basiert auf dem liberalen Feminismus und besagt, dass Frauen einen schlechteren Zugang zu Ressourcen wie Bildung, Berufserfahrung und finanziellen Mitteln haben. Nach dem zweiten Ansatz, der auf dem sozialen Feminismus beruht, haben Frauen andere Einstellungen und Werte als Männer und wählen entsprechend eine andere unternehmerische Herangehensweise.

Dieses Papier soll einen Beitrag zum besseren Verständnis des schlechteren Abschneidens der von Frauen gegründeten Unternehmen leisten. Dabei werden Performancemaße verwendet, die das Wachstum, die Größe und die Rentabilität des Unternehmens abbilden. Die Datengrundlage bilden etwa 4.700 deutsche Unternehmen aus dem KfW/ZEWGründungspanel, deren Performance über maximal vier Jahre seit der Gründung beobachtet werden kann. Es wird untersucht, ob und inwieweit der unterschiedliche Unternehmenserfolg der Unternehmensgründungen von Frauen und Männern auf geschlechtsspezifische Unterschiede in der formalen Bildung, der Berufserfahrung, der Größe des Gründerteams, der Gründungsmotivation und der Branchenwahl zurückgeführt werden kann.

Es zeigt sich, dass Gründungen von Frauen bei allen Performancemaßen schlechter abschneiden. Außerdem gibt es signifikante Geschlechtsunterschiede bei vielen beobachteten Merkmalen. Im Vergleich zu männlichen Gründern haben Gründerinnen ein geringeres formales Bildungsniveau, weniger Berufserfahrung, gründen in kleineren Teams, gründen häufiger aus der Not und sind im Einzelhandel, im Dienstleistungssektor und allgemein in Low-Tech-Branchen überrepräsentiert. Diese Unterschiede können das schlechtere Abschneiden der Gründungen von Frauen zum Teil erklären. Jedoch hängt der Erklärungsbeitrag der einzelnen Merkmalsunterschiede stark vom betrachteten Performancemaß ab.

Unsere Ergebnisse liefern weder einen eindeutigen Beweis für den liberalen noch den sozialen feministischen Ansatz. Ersterer wird zwar dadurch gestützt, dass geschlechtsspezifische Unterschiede bei den Ressourcen (Humankapital, Teampartner) die Performancelücke bei Wachstum und Umsatz zumindest teilweise erklären. Wir zeigen aber auch, dass die Lücke bei der Rentabilität sogar zunimmt, wenn man die Unterschiede bei der Anzahl Teampartner und der unternehmerischen Erfahrung berücksichtigt. Gegen den sozialen feministischen Ansatz, der impliziert, dass Frauen ebenso effiziente Manager sind wie Männer, spricht die geringere Rentabilität der Gründungen von Frauen. Auch finden wir keine Unterschiede im Ausmaß der Gewinnorientierung von Gründerinnen und Gründern. Allerdings sind Gründerinnen offenbar weniger wachstumsorientiert.

Leider stehen uns keine Informationen zur Arbeitszeit, die die Gründerinnen und Gründer in ihr Unternehmen investieren, zur Verfügung. Demnach sind wir nicht in der Lage zu testen, inwieweit Gründerinnen durch familiäre Verpflichtungen - z.B. Kinderbetreuung oder Pflege von Angehörigen - stärker beansprucht sind als Gründer. Der geringere Erfolg der Unternehmen von Frauen könnte auch auf solche zeitlichen Restriktionen zurückzuführen sein. Ferner fehlen uns Informationen zu Persönlichkeitsmerkmalen wie der Risikoeinstellung und dem Selbstvertrauen, die das unternehmerische Verhalten und letztlich den unternehmerischen Erfolg beeinflussen können. 


\title{
Gender Differences in Business Success of German Start-up Firms
}

\author{
Sandra Gottschalk
}

Michaela Niefert

Keywords: Start-ups, performance, gender, female entrepreneurship

JEL: L25, L26, J16 


\section{Introduction}

Today, $45 \%$ of the employees in Germany are female whereas the rate of female business owners is much lower. Only about $20 \%$ of the newly established firms in Germany are majority-led by women (Metzger et al. 2008). In the USA, the rate of female business ownership is somewhat higher but still lags behind female labour participation. According to the Center for Womens's Business Research, 29\% of all privately held businesses in the U.S. were majority-owned by women (Gatewood et al. 2009). Low female business ownership rates are a common phenomenon in industrialized countries. According to the Global Entrepreneurship Monitor (GEM), self-employment rates of women are about half the rates for men (Minniti et al. 2006).

Women-owned businesses are not only fewer but are also characterized by lower outcomes than their male-owned counterparts. Empirical studies have revealed that womenowned firms underperform in aggregate comparisons for a variety of performance indicators like sales, employment, income and growth (e.g., Loscocco et al. 1991, Rosa et al. 1996, Du Rietz and Henrekson 2000). Performance differences by gender may be explained by systematic gender differences in characteristics affecting business outcome. There are two theoretical perspectives on likely causes of female underperformance. Liberal feminist theory suggests that women lack access to relevant resources like education and business experience or financial capital. Social feminist theory suggests that women have different attitudes and values and, consequently, adopt a different approach to business.

To evaluate these theories and to shed light on the causes of female underperformance, empirical studies have analyzed gender differences in industry choice, start-up capital, education, experience, family situation, business goals and attitudes, and investigated the impact of these variables on performance (Kalleberg und Leicht 1991, Loscocco et al. 1991, Fischer et al. 1993, Rosa et al. 1996, Du Rietz and Henrekson 2000, Hundley 2001, Watson 2002, Fairlie and Robb 2009). However, very few variables were consistently identified which both differ between men and women and relate to performance in a way that they can explain female underperformance. Thus, quite little is still known about why female-owned businesses underperform and which of the two theories best explain this phenomenon.

This paper intends to add knowledge on the reasons for the female/male performance gap. We investigate gender differences in business outcome using performance indicators related to size, growth and profitability, and draw on a data set of about 5,500 German start-up firms. The data contains comprehensive information on the characteristics of the firm, the founder's education and experience, and his/her motivation and goals, and thus allows us to address both theoretical approaches. Employing a variation of the standard Blinder-Oaxaca decomposition, we analyze to what extent the gender gap in performance can be allocated to gender differences in observable characteristics like education, experience, team size, motivation and industry choice.

The paper is organized as follows. In the subsequent section, the previous literature is discussed with regard to the underlying theoretical considerations concerning the performance gap between male and female founders. Our research hypotheses derived from those theories are presented afterwards. The firm data and methods we use are introduced in the next section. In the section "results" we discuss our findings and conclude with a prospect for further research in the future. 


\section{Previous Research}

Many empirical studies comparing the business performance by gender at the aggregate level found lower outcomes in terms of sales, employment, income, profits and growth for women-owned businesses (Loscocco et al. 1991, Fischer et al. 1993, Rosa et al. 1996, Fasci and Valdez 1998, Du Rietz and Henrekson 2000, Hundley 2001, Coleman 2002, Watson 2002, Fairlie and Robb 2009, Gatewood et al. 2009). The evidence is less clear for profitability related measures. Various studies indicate women-owned businesses perform as well as men-owned businesses when looking at return on assets or return on investment (Fischer et al. 1993, Chaganti and Parasumaran 1996, Coleman 2002, Watson 2002, Robb and Watson 2010).

The observed differences in size and growth related performance indicators may be explained by systematic gender differences. Women and men may differ in their preferences for industries. Female entrepreneurs tend to choose sectors that are associated with low sales and growth. There may also be gender differences in characteristics like education, experience, or attitudes which impact business outcome. There are two theoretical perspectives for explaining gender differences in business performance (Fischer et al. 1993). Liberal feminist theory suggests that women are disadvantaged relative to men because they lack access to human capital, i.e. education and professional experience, or financial capital. This lack of access to resources impedes their ability to succeed in business. The disadvantage of females is grounded in overt discrimination and in the ways that women's socialization discourages them from developing their full capacities. If equal access is ensured, gender differences in performance will disappear. In contrast, social feminist theory suggests that women differ inherently due to differences in early socialization. They have a different attitude towards risk and growth and pursue different goals. Consequently, they adopt a different approach to business, resulting in smaller firm size and a lower rate of expansion. However, this does not imply they are less effective in business than men. ${ }^{1}$

Despite their differing assumptions on the causes of gender differences in business performance, the two theories are not in complete conflict. Differences in resource endowment and differences in values and attitudes may be concomitant factors explaining female underperformance. Accordingly, some empirical studies consider both variables related to the founder's resources (for example education, experience, start-up capital, family situation, and working hours), and the founder's attitudes and values (for example risk aversion, internality of locus of control, growth propensity, and founding strategy) when analyzing gender differences in business performance (Kalleberg and Leicht 1991, Loscocco et al. 1991, Fischer et al. 1993, Rosa et al. 1996, Carter et al. 1997). Other studies either focus entirely on the founders' resources (Hundley 2001, Swinney et al. 2006, Fairlie and Robb 2009, Robb and Watson 2010) or on their attitudes and values (Du Rietz and Henrekson 2000) in addition to industry-related variables.

Empirical evidence does not clearly verify one of these theories or discard the other. Regarding liberal feminist theory, there is some evidence that a lack of specific resources impedes women from succeeding in business, while the evidence is less clear for other types of resources. As to human capital, it seems that differences in experience contribute more to the performance gap than differences in education. Several studies indicate that

\footnotetext{
${ }^{1}$ Liou and Aldrich (1995) describe two distinct perspectives on gender differences in performance, namely the situational versus the dispositional perspective, which are similar to the liberal and social feminist theory, respectively. According to the situational perspective, gender differences in performance result from unequal access to opportunities in labor markets and organizations and its consequences for the acquisition of skills and capabilities. Alternatively, dispositional proponents argue that variations in the education and socialization of men and women lead to differences in experiences, ways of thinking, values and hence in the business owner's motives and intentions.
} 
women have less experience in the industry of their current business and less entrepreneurial experience than men, and that such experience has a positive impact on performance (Loscocco et al. 1991, Fischer et al. 1993, Carter et al. 1997, Hundley 2001, Fairlie and Robb 2009). Moreover, it was found that women have less managerial experience than men, but the contribution of this difference to the gender gap seems to be small, insignificant or even negative for certain performance indicators (Fischer et al. 1993, Boden and Nucci 2000, Fairlie and Robb 2009). As to education, studies indicate that differences in the educational level only explain a small part of the performance difference (Hundley 2001, Fairlie and Robb 2009). Other studies fail to discover any gender differences in education or to find a significant impact of education on performance (Loscocco et al. 1991, Fischer et al. 1993, Rosa et al. 1996).

As to financial capital, the fact that female business owners start with lower levels of capital has been explained to a large part by the specific characteristics of their businesses. There is almost no evidence of gender discrimination by lenders as suggested by liberal feminist theory (Riding and Swift 1990, Fabowale et al. 1995, Carter and Rosa 1998, Coleman 2000 and 2002, Verheul and Thurik 2001, Orser et al. 2006). Moreover, evaluating the impact of gender differences concerning the level of capital on the performance gap is complicated by endogeneity problems. Without controlling for endogeneity, Fairlie and Robb (2009) find that the smaller amount of start-up capital used by female entrepreneurs explains a substantial part of the performance gap. Hundley (2001) controls for endogeneity and reports a smaller but still tangible contribution of gender differences in business capital to the gap. Boden and Nucci (2000) find evidence only in one of the two cohorts they analyzed that female owners' tendency to use less start-up capital narrows the survival prospects of their businesses compared to male owners.

Referring to time and energy, it is evident that female entrepreneurs are more strained by domestic responsibilities and work less hours in business than men (Goffee and Scase 1985, Loscocco et al. 1991, Cliff 1998, Hundley 2001, Fairlie and Robb 2009). Further studies indicate that this relative lack of time and energy explains part of the gender difference in earnings from self-employment. Loscocco et al. (1991) report that the greater tension experienced by women between business and family leads to a lower personal income when running a business. Hundley finds that gender differences in the distribution of labor hours between market work and household production make the most marked contribution to the male/female earnings differential in self-employment. The effect of family responsibilities and work hours on other business performance indicators, however, is not clear (Rosa et al. 1996, Robb and Watson 2010). The evaluation of this effect is also made difficult by the potential endogeneity of work hours with respect to performance (Fairlie and Robb 2009).

Similarly, social feminist theory is not entirely supported by empirical findings. To begin with, size-related performance indicators like sales, employment or growth are usually significantly greater for men than women, while indicators relating outputs to inputs like return on assets mostly do not differ by gender (e.g. Watson 2002). This is in line with social feminist theory which states that women adopt a different approach to business resulting in a smaller firm size and a lower rate of expansion, but act not necessarily less effectively in business than men.

However, empirical evidence does not support the assumption that female entrepreneurs choose to establish a smaller firm size and grow at a lower rate because they have different attitudes and values. Studies have documented few if any consistent gender differences in socialized traits and values. There is some evidence that women place less value on growth and have a lower risk-taking propensity (Sexton and Bowman-Upton 1990, Rosa et al. 1996). However, Cliff (1998) states that male and female entrepreneurs are equally likely 
to desire business growth, but that females are more concerned with the risk of fast-paced growth and tend to deliberately adopt a slow and steady rate of expansion. In turn, Loscocco et al. (1991) find that women are more likely than men to espouse risk taking. They suggest that, given the greater obstacles facing women in the small business arena, the selection of those with a propensity for risk taking in business ownership is stronger for females than for males. Moreover, Fischer et al. (1993) find that women have even a stronger financial motivation than men. Rosa et al. (1996) stress in their literature review that "there is no evidence that men are any more profit orientated than women, or any less likely to value intrinsic goals.” A current study by Furdas and Kohn (2010) fails to find significant gender differences regarding various personality traits including risk tolerance for entrepreneurs in Germany. All in all, it seems there is greater similarity than difference in psychological characteristics and values between male and female entrepreneurs (Fagenson 1990, Sexton and Bowman-Upton 1990, Kalleberg and Leicht 1991, Loscocco et al. 1991).

Nevertheless, empirical evidence indicates that being strained by family responsibilities impacts women's motivation and intention to become an entrepreneur. Many women start a business to create flexible work schedules that allow them to care for their families (Scott 1986, Döbler 1998, Boden 1999). Financial goals are of inferior importance because women are often not the household's principal earner. But this difference in business aims is rather a consequence of a gender-specific role allocation than of gender differences in socialized traits and values. Within the limited time women are able to work during the work week, women just like men seem to strive for profit maximization.

Differences in industry distribution might be another reason for the male/female gap in business performance. Female-owned businesses are overrepresented in retail trade and services and underrepresented in manufacturing and construction (Loscocco et al. 1991, OECD 1998, Du Rietz and Henrekson 2000, Fairlie and Robb 2009). Thus, they tend to operate in sectors which are characterized by intense competition and high business failure rates. The industry choice of female entrepreneurs may either be the result of capital constraints, skill differences, discrimination or differences in preferences (Fairlie and Robb 2009). Accordingly, gender differences in industry distribution may be viewed from the theoretical perspective of liberal or social feminism. While it is evident that differences in industry distribution explain part of the female underperformance, estimates on the relative contribution of these differences are inconsistent across studies. Loscocco et al. (1991) attribute a high importance to industry differences in explaining female underperformance with respect to sales and income. Similarly, Hundley (2001) shows that a large part of the earnings gap in self-employment is explained by gender differences in industry choice. By contrast, Fairlie and Robb (2009) conclude that industry differences are not one of the major factors affecting the performance gap.

To sum up, the gender discrepancy in business performance has not yet been fully explained by empirical studies. Only very few variables were consistently found which differ between men and women and at the same time relate to performance in a way that they explain female underperformance. After controlling for potential determinants of the female/male performance gap, studies often still find a significant negative effect of female business-ownership on size and growth related performance indicators (Loscocco et al. 1991, Rosa et al. 1996, Fasci and Valdez 1998, Fairlie and Robb 2009). Moreover, the causes of the performance gap seem to differ according to the performance indicator considered. 


\section{Research Hypotheses}

The literature review shows there are a variety of factors that could explain why femaleowned businesses underperform, but there is conflicting empirical evidence on which of these factors really contributes to the performance gap. We focus our interest on human capital, entrepreneurial motivation and industry choice and derive four hypotheses from the literature.

Our first hypothesis reproduces the argument of liberal feminist theory that females lack access to entrepreneurially relevant human capital. Both formal education and professional experience may provide the founder with entrepreneurially relevant knowledge. According to the empirical evidence, however, it is first of all lack of experience and not lack of education which explains female underperformance. We split the two aspects into two parts:

Hypothesis 1a: Female founders have lower human capital in terms of education and experience than male founders - therefore their businesses underperform.

Hypothesis 1b: Differences in professional experience contribute more to the performance gap than differences in formal education.

There is another factor related to human capital which has hardly been accounted for in the relevant literature so far, namely team size. The number of founders or owners in the team might have a positive impact on performance because the variety of skills, knowledge and talents in the management team increases with it. There is some empirical evidence for such a positive effect (Teach et al. 1986, Doutriaux 1992, Müller 2010). Female underperformance might then partly be explained by the fact that females are less likely to start a business with partners (Cuba et al. 1983, Carter et al. 1997) and that start-up teams formed by females are relatively small (Rosa et al. 1996).

Hypothesis 2: Female founders start their business with fewer partners than male founders and are more likely to start them without any partners - therefore their businesses underperform.

Our third hypothesis refers to entrepreneurial motivation. It is maintained that being strained by family responsibilities impacts women's motivation to become an entrepreneur. While most men are primarily motivated by the wish to realize and exploit a concrete business idea, many women first of all aim at creating flexible work schedules. Women might also become self-employed because they are unable to find a job as an employee after having suspended their employment history for family reasons. Being driven primarily by lifestyle reasons or necessity should have a detrimental effect on female business performance.

Hypothesis 3: Female founders differ from male founders in their entrepreneurial motivation - therefore their businesses underperform.

Finally, we test the hypothesis that female entrepreneurs underperform because of their preference for less remunerative industries like retail and services. We further analyze whether female-founded firms are generally underrepresented in high-tech industries that are supposed to be particularly lucrative because they are characterized by fast-paced growth and a low degree of competitive pressure.

Hypothesis 4: Female founders often start their business in the retail and services sectors and generally in low-tech industries - therefore their businesses underperform. 


\section{Data and method}

\section{Data Source}

We use a data set of about 4,700 German firms established between 2005 and 2008. It is derived from the KfW/ZEW Start-Up Panel, a panel of German start-ups in a broad range of industries which was launched in 2008. The panel is a joint activity of the "KfWBankengruppe," a publicly owned bank; the Centre for European Economic Research (ZEW); and Creditreform, Germany's biggest credit rating agency. The underlying firm population, from which a stratified ${ }^{2}$ random sample was drawn, is composed of all startups recorded by Creditreform which are operating in manufacturing, construction and services and were founded in the years 2005 to 2008. In the following years these firms shall be observed up to a firm age of seven years.

Our analysis is based on the first three survey waves that were conducted in 2008, 2009 and 2010. The data contain comprehensive information on the characteristics of the firm, the amount of start-up capital used, and the founders' education, experience, previous employment status, entrepreneurial motivation and business goals. They also provide information on the number and gender of founders. Moreover, the data contain longitudinal information on employment, sales and profits, so that it is possible to construct performance indicators relating to size, growth and profitability.

\section{Measures}

We compare the performance of male and female-founded businesses with respect to employment growth, sales and return on sales. Thus, we do not limit our analysis to size and growth related performance measures as many previous studies have. Instead, by using return on sales, we also consider profitability and are therefore able to analyze whether a possibly larger size of male-founded firms pays off in form of higher profits. We also take into account that the relation between employment growth and firm size depends on the growth measure considered. Relative growth typically declines with firm size, whereas absolute growth increases with it. We therefore calculate employment growth both in relative and absolute terms in order to obtain a more complete picture of the determinants of employment creation. The exact definitions of the performance indicators and the other variables used in the empirical analysis are given in Table 2.

Table 1: Start-ups by gender of the founder(s)

\begin{tabular}{lrr}
\hline & Obs. & Share \\
\hline Single founder man & 2795 & $60.0 \%$ \\
Single founder woman & 465 & $10.0 \%$ \\
Team founders men only & 971 & $20.9 \%$ \\
Team founders women only & 38 & $0.8 \%$ \\
Team founders men and women & 385 & $8.3 \%$ \\
\hline Sum of firms & 4654 & $100 \%$ \\
\hline Source: KfW/ZEW Start-Up Panel & &
\end{tabular}

The definition of a firm as male or female-owned is somewhat difficult in the case of co-ownership. Previous studies have usually classified firms that are owned by both men and women into female (male) headed firms according to the gender which has the majority in the team (Carter et al. 1997) or according to the gender of the major decision-maker or the person playing the chief managerial role in the team (Fischer et al. 1993, Du Rietz

\footnotetext{
${ }^{2}$ Stratification criteria are the year of establishment, the industry and KfW-funding.
} 
and Henrekson, Watson 2001, 2002). In contrast, we follow the approach chosen by Johnsen and McMahon (2005) and separate mixed gender teams out because we believe that this will yield more robust findings regarding gender differences. We define a business as female-founded if there is at least one female founder and no male founder. Conversely, a business is defined as male-founded if there is at least one male founder and no female founder. Using this definition, we find that $10.8 \%$ of the firms in our sample are femalefounded, $80.9 \%$ are male-founded, and $8.3 \%$ were founded by mixed teams (Table 1 ).

When specifying the regression model we try to capture as many of the factors which are supposed to impact performance and to differ by gender as possible. As to the founder specific variables, we first consider the number of founders in order to disentangle the effects of gender and team size on performance. Second, we include various variables describing the founder's human capital. These variables refer to the level of formal education and several dimensions of professional experience (industry-specific, managerial, entrepreneurial). General professional experience should be broadly captured by the founder's age. But age might also be an indicator of the founder's risk taking propensity. In addition, there are two indicator variables on the employment history, namely whether the founder has been unemployed or not employed before start-up.

Third, we use information on the founders' primary motivation which enables us to classify them as opportunity entrepreneurs, necessity entrepreneurs and founders aiming at self-determination at work. We assume that someone who starts a business primarily in order to create flexible work schedules and to be able to combine business and family work would assign to the self-determination motive. Thus, we think that we can at least indirectly capture the impact of family commitments on performance using this variable. This is important since we do not have more direct information on family responsibilities like the number of children or the number of hours worked in the firm.

Moreover, we have information on the founders' business goals. Respondents were asked to rank several potential goals (profit, jobs, positive company image, strong market position, support of home region, environmental protection) according to the importance they attach to them. In principle, this allows us to assess whether female entrepreneurs are less profit orientated and more interested in intrinsic goals than males as suggested by social feminist theory. However, this question was not asked at the time of foundation but at some point of time during the first business years. Thus, it is possible that respondents have adapted their goals to the actual business performance. For example, they might tend to say that generating profit is not of primary importance if they were not very successful in generating profits so far. We decided not to include this variable in the performance regressions because of its potential endogeneity, but we compare the goals between males and females at the descriptive level.

As to the firm specific variables, we consider the firm's initial size, age, R\&D activity, legal form (limited company) and industry. Firm's initial size is measured in employment and start-up capital. Start-up capital and legal form turned out to be endogenous in the performance regression. Since we have no adequate instruments to run an instrumental variable regression, we run two versions of the performance regressions, one with start-up capital and legal form as right-hand side variables and one without. The categorization of industries used allows us to differentiate between high-tech industries (new technology based manufacturing, new technology based services, software) and lower-tech industries. 
Table 2: Description of variables

Variable Description

\section{Dependent variables}

Employment growth - relative

Geometrical growth rate of total employment measured in full time equivalents between firm foundation and 2009

Employment growth - absolute

Difference in total employment measured in full time equivalents between firm foundation and 2009

Sales 2009

Return on sales

Log of total sales in 2009

Share of profit (or loss) in total sales in 2009

\section{Explanatory variables}

Founder specific variables

Female

Mixed team

Team size

Log(Founder's age)

Graduate

Master craftsman

Apprenticeship

Log (experience in industry)

Entrepreneurial experience

Managerial experience

Unemployed before

Not employed before

Motive: opportunity

Motive: necessity

Motive: self-determination

Goal: profit / creating jobs / ... / support of the home region

Single founder is female / at least one female founder and no male founder in the team of founders (dummy 0,1)

At least one female founder and one male founder in the team of founders (dummy 0,1)

Number of founders (equals 0 for not-team foundations)

Logarithm of the (oldest) founders' age in years

Single founder is a university graduate / at least one graduate in the team of founders (dummy 0,1)

Single founder has a master craftsman diploma / at least one graduate in the team of founders (dummy 0,1)

Single founder completed an apprenticeship education / at least one graduate in the team of founders (dummy 0,1)

Logarithm of the years of professional experience of the founder / of the most experienced founder in the same industry

Single founder has entrepreneurial experience / at least one founder has entrepreneurial experience in the team of founders (dummy 0,1)

Single founder has been a top manager / at least one founder has been a top manager in the team of founders before firm foundation (dummy 0,1)

Single founder has been registered unemployed / at least one founder in the team of founders has been registered unemployed before firm foundation (dummy 0,1)

Single founder has been not employed / at least one founder in the team of founders has been not employed before firm foundation (dummy 0,1)

Firm foundation was based on a precise business idea or market gap (dummy 0,1)

Firm foundation was driven by necessity (unemployment or no adequate dependent employment) (dummy 0,1)

Firm foundation was driven by the wish to be self-determined at work (dummy 0,1)

Firm specific variables

Start-up size

Log(Start-up capital)

R\&D

Generating profit / creating jobs / ... / support of the home region is a main business goal (dummy 0,1)

Number of employees at start-up (full-time equivalent), excluding founders

Logarithm of the amount of start-up capital used in the foundation year

Firm is conducting R\&D (dummy 0,1)

Limited company 


\begin{tabular}{ll}
\hline Firm age & Firm's age in years \\
NTB manufacturing & $\begin{array}{l}\text { Firm belongs to new technology-based manufacturing industries (dummy } \\
0,1)\end{array}$ \\
NTB services & $\begin{array}{l}\text { Firm belongs to new technology-based service industries excluding soft- } \\
\text { ware (dummy 0,1) }\end{array}$ \\
Software & Firm belongs to software industry (dummy 0,1) \\
Other manufacturing & $\begin{array}{l}\text { Firm belongs to other manufacturing industries than NTB manufacturing } \\
\text { industries (dummy 0,1) }\end{array}$ \\
Construction & $\begin{array}{l}\text { Firm belongs to construction industry (dummy 0,1) } \\
\text { Knowledge-intensive services } \\
\text { Other firm-related services }\end{array}$ \\
Consumer-related services & $\begin{array}{l}\text { Firm belongs to knowledge-intensive service industries (dummy 0,1) } \\
\text { Firm belongs to other consumer-related service industries (dummy 0,1) }\end{array}$ \\
\hline
\end{tabular}

Method of analysis

We first use descriptive statistics to compare women-founded and men-founded firms in the sample. Second, we perform regressions of each performance indicator on the set of explanatory variables including the sex of the founder. Finally, employing a variation of the Blinder-Oaxaca decomposition, we analyze to what extent the gender gap in performance can be allocated to gender differences in these variables and calculate the relative contribution of gender differences in specific variables to the gap.

The standard Blinder-Oaxaca decomposition for linear regression models reduces the performance gap (the mean outcome difference $\bar{y}_{M}-\bar{y}_{W}$ ) to two component parts: one, due to differences in the characteristics of men $\left(x_{M}\right)$ and women $\left(x_{W}\right)$ and second, due to differences in the coefficients of separate linear regression equations for men and women ( $\beta_{M}$ and $\beta_{W}$ ) (Blinder, 1973, Oaxaca, 1973):

(A) $\bar{y}_{M}-\bar{y}_{W}=\left(\bar{x}_{M}-\bar{x}_{W}\right) \beta_{M}+\bar{x}_{w}\left(\beta_{M}-\beta_{W}\right)$ and

(B) $\bar{y}_{M}-\bar{y}_{W}=\left(\bar{x}_{M}-\bar{x}_{W}\right) \beta_{W}+\bar{x}_{M}\left(\beta_{M}-\beta_{W}\right)$

The components can be calculated using the coefficients and characteristics of either men or women as weights for the two components of the performance gap.

The second component of equations (A) and (B) representing differences in the coefficients is supposed to capture behavioural differences. For example, if the coefficient of formal education differed by gender, this would imply that male and female entrepreneurs receive different returns on education. In other words, they derive different benefits from education for business so that their businesses will perform differently even if they are equally endowed with education. However, the differences in returns are probably caused by differences in unobserved characteristics affecting performance (e.g. entrepreneurial ability or risk attitude) which are correlated with education or interact with education in the performance regression. It is hard to imagine why returns on education should otherwise differ by gender. Thus, the differences should disappear once it is adequately controlled for these factors. In general, differences in coefficients will rather be a result of unobserved heterogeneity than of true behavioural differences. Accordingly, Fairlie and Robb (2009) point out the sensitivity of the standard Blinder-Oaxaca decomposition technique due to specification errors. Further, Jones (1983) demonstrates another drawback of this technique, namely its sensitivity with regard to alternative scales of explanatory variables. 
On the one hand we find that the coefficients of the separate regressions for men and women differ significantly ${ }^{3}$, but on the other hand interaction terms between the indicator variable "female" and the explanatory variables mostly turn out to be insignificant in the joint regression. ${ }^{4}$ According to the argumentation above we assume that this conflicting result can be traced to unobserved factors affecting performance. Following Fairlie and Robb (2009) and Oaxaca and Ransom (1994), we therefore decided to use an alternative technique in computing only the first part of the decomposition and using coefficient estimates $\hat{\beta}_{M, W}$ from a pooled sample of the firms founded by men and women (excluding firms founded by mixed teams): $\left(\bar{x}_{M}-\bar{x}_{W}\right) \hat{\beta}_{M, W}$. We calculate the contributions of each explanatory variable $x^{j}$ to the performance gap for each of the three performance regressions: $\left(\bar{x}_{M}^{j}-\bar{x}_{W}^{j}\right) \hat{\beta}_{M, W}^{j}{ }^{5}$

\section{Results}

\section{Descriptive Analysis}

We find that male-founded businesses outperform female-founded businesses in all performance indicators considered (Table 3). They grow faster in relative and absolute terms, have larger sales and are more profitable as indicated by higher returns on sales. Thus, contrary to several other studies, we find that females also underperform in terms of profitability even though the difference is statistically significant, but only on a low level.

Comparing the founder specific variables between male and female founders, we find that females are often single owners and have less founding partners on average. Only $7.3 \%$ of the female start-ups were founded by teams as compared to $25.5 \%$ of the male start-ups, and female teams are smaller on average than male teams (Table 3). Thus, the first part of Hypothesis 2 is confirmed.

Female entrepreneurs are lower-qualified both in terms of the educational level and in terms of professional experience. Even though they are four years older on average than their male counterparts, they have less industry, entrepreneurial and managerial experience. This result supports the first part of Hypothesis 1a.

A higher share of females than males has been registered unemployed or not employed before start-up. Even though the share of females starting from outside the labor force is

\footnotetext{
${ }^{3}$ A likelihood-ration-test further indicates to use separate equations for men and women.

${ }^{4}$ We compute interaction terms for the gender dummy and the explanatory variables "graduate", "entrepreneurial experience”, "managerial experience”, “start-up capital”, "experience in industry”, “not employed before" and "industry sector". The regression results for the three performance equations including the interaction terms reject the existence of gender specific effects on performance. Only the interaction term "not employed before and female" has a significantly negative effect on return on sales.

${ }^{5}$ To check the robustness of our results we carried out a Monte-Carlo analysis which is similar to a procedure applied by Fairly (2005). We used the coefficient estimates of the pooled regression and computed the predicted performance for each equation. Next we drew a random subsample of men-founded firms which is equal in size to the full sample of women-founded firms, to take into account that the sample sizes differ considerably. The random sample of men-founded firms and the full sample of women-founded firms were used to calculate the contributions of the founders' characteristics to the performance gap for each equation. We repeated the procedure 100 times and computed the means and standard errors of the different runs. In comparison to the decomposition using the whole sample (which is further discussed and shown in Table 5 and Table A2), the results of the Monte-Carlo simulation turned out to be not significantly different. Hence, robustness of our decomposition results is shown.
} 
not significantly higher than the corresponding share of males, this indicates that women often start a business after a disruption in their employment history. Therefore it is not surprising that their start-ups are relatively often driven by necessity and rather infrequently based on an opportunity. Given the higher share of females starting from outside the labor force we would have expected that these women interrupted their career for family reasons and are particularly interested in flexible work schedules to be able to comply with family and work responsibilities. But we do not observe that female entrepreneurs are driven by the self-determination motive more often than their male counterparts. Altogether, however, there are significant gender differences in entrepreneurial motivation, so that the first part of Hypothesis 3 is confirmed.

The business goals, however, are largely the same for male and female entrepreneurs. Both sexes are mostly interested in generating profits, while other goals like a positive company image or environmental protection are of minor importance. The only significant difference that shows up concerns the goal of a strong market position. A larger share of males than females states that this was their main business goal. This might indicate that female entrepreneurs are less eager for expansion, but not less profit-oriented and not more attached to intrinsic goals than their male counterparts. This finding is largely in line with the previous literature.

Comparing the firm specific variables, it shows that female entrepreneurs do not start smaller in terms of the number of employees. However, they use less start-up capital than male and rarely choose a limited company as legal form. The two aspects are interrelated since founding a limited company requires inserting a certain amount of registered capital. Female-founded firms are considerably less likely to conduct $R \& D$. They are rarely new technology based firms and are particularly underrepresented in the software industry. Outside the high tech sector, they are overrepresented in the services and retail industry and underrepresented in the manufacturing and construction industry. The first part of Hypothesis 4 is hence confirmed. 
Table 3: Comparison of female and male founders and their firms

\begin{tabular}{|c|c|c|c|c|}
\hline Variable & Obs. & $\begin{array}{c}\text { Mean } \\
\text { (Std. dev.) }\end{array}$ & Obs. & $\begin{array}{c}\text { Mean } \\
\text { (Std. dev.) }\end{array}$ \\
\hline & \multicolumn{2}{|c|}{ Men } & \multicolumn{2}{|c|}{ Women } \\
\hline Dependent variables ${ }^{1}$ & & & & \\
\hline Employment growth - relative & 3234 & $\begin{array}{r}0.265^{* *} \\
(0.480)\end{array}$ & 473 & $\begin{array}{r}0.203^{* *} \\
(0.391)\end{array}$ \\
\hline Employment growth - absolute & 3231 & $\begin{array}{r}1.66^{* *} \\
(3.12)\end{array}$ & 469 & $\begin{array}{r}1.24 * * \\
(2.64)\end{array}$ \\
\hline Sales 2009 (in thousand $€$ ) & 2561 & $\begin{array}{r}360 * * * \\
(545)\end{array}$ & 318 & $\begin{array}{r}237 * * * \\
(376)\end{array}$ \\
\hline Return on sales ${ }^{2}$ & 1797 & $\begin{array}{c}0.144^{*} \\
(0.261)\end{array}$ & 204 & $\begin{array}{c}0.100 * \\
(0.302)\end{array}$ \\
\hline \multicolumn{5}{|l|}{ Explanatory variables } \\
\hline \multicolumn{5}{|l|}{ Founder specific variables } \\
\hline Team & 3692 & $\begin{array}{r}0.255^{* * *} \\
(0.436)\end{array}$ & 494 & $\begin{array}{r}0.073 * * * \\
(0.260)\end{array}$ \\
\hline Team size & 940 & $\begin{array}{r}2.41^{* *} \\
(0.85)\end{array}$ & 36 & $\begin{array}{r}2.06 * * \\
(0.23)\end{array}$ \\
\hline Founder's age & 3692 & $\begin{array}{r}38.7 * * * \\
(15.5)\end{array}$ & 494 & $\begin{array}{r}42.8^{* * *} \\
(10.7)\end{array}$ \\
\hline Graduate & 3684 & $\begin{array}{r}0.399 * * * \\
(0.490)\end{array}$ & 492 & $\begin{array}{r}0.313^{* * *} \\
(0.464)\end{array}$ \\
\hline Master craftsman & 3684 & $\begin{array}{r}0.289 * * \\
(0.453)\end{array}$ & 492 & $\begin{array}{r}0.226^{* *} \\
(0.418)\end{array}$ \\
\hline Apprenticeship & 3684 & $\begin{array}{r}0.281^{* * *} \\
(0.449)\end{array}$ & 492 & $\begin{array}{r}0.441^{* * *} \\
(0.497)\end{array}$ \\
\hline Experience in industry (years) & 3677 & $\begin{array}{r}16.9 * * * \\
(9.4)\end{array}$ & 491 & $\begin{array}{r}14.3^{* * *} \\
(9.5)\end{array}$ \\
\hline Entrepreneurial experience & 3689 & $\begin{array}{r}0.328 * * * \\
(0.470)\end{array}$ & 494 & $\begin{array}{r}0.190 * * * \\
(0.393)\end{array}$ \\
\hline Managerial experience & 3682 & $\begin{array}{r}0.414^{* *} \\
(0.493)\end{array}$ & 493 & $\begin{array}{r}0.339 * * \\
(0.474)\end{array}$ \\
\hline Unemployed before & 3682 & $\begin{array}{r}0.148 * * * \\
(0.355)\end{array}$ & 493 & $\begin{array}{r}0.211^{* * *} \\
(0.408)\end{array}$ \\
\hline Not employed before & 3682 & $\begin{array}{r}0.070 \\
(0.256)\end{array}$ & 493 & $\begin{array}{r}0.089 \\
(0.285)\end{array}$ \\
\hline Motive: self-determination & 3692 & $\begin{array}{r}0.46 \\
(0.498)\end{array}$ & 494 & $\begin{array}{r}0.47 \\
(0.499)\end{array}$ \\
\hline Motive: opportunity & 3692 & $\begin{array}{r}0.316^{* *} \\
(0.465)\end{array}$ & 494 & $\begin{array}{r}0.245^{* *} \\
(0.430)\end{array}$ \\
\hline Motive: necessity & 3692 & $\begin{array}{r}0.152^{* * *} \\
(0.359)\end{array}$ & 494 & $\begin{array}{r}0.227 * * * \\
(0.419)\end{array}$ \\
\hline Goal: profit & 2604 & $\begin{array}{r}0.64 \\
(0.48)\end{array}$ & 349 & $\begin{array}{r}0.68 \\
(0.47)\end{array}$ \\
\hline Goal: creating jobs & 2604 & $\begin{array}{r}0.10 \\
(0.30)\end{array}$ & 349 & $\begin{array}{r}0.11 \\
(0.31)\end{array}$ \\
\hline Goal: positive company image & 2604 & $\begin{array}{r}0.08 \\
(0.27)\end{array}$ & 349 & $\begin{array}{r}0.07 \\
(0.25)\end{array}$ \\
\hline Goal: strong market position & 2604 & $\begin{array}{r}0.08 * * \\
(0.27)\end{array}$ & 349 & $\begin{array}{r}0.05^{* *} \\
(0.21)\end{array}$ \\
\hline Goal: environmental protection & 2604 & $\begin{array}{r}0.01 \\
(0.11)\end{array}$ & 349 & $\begin{array}{r}0.01 \\
(0.09)\end{array}$ \\
\hline Goal: support of the home region & 2604 & $\begin{array}{r}0.003 \\
(0.059)\end{array}$ & 349 & $\begin{array}{r}0.006 \\
(0.076)\end{array}$ \\
\hline Firm specific variables & & & & \\
\hline Start-up capital (in thousand $€$ ) & 3216 & $\begin{array}{l}83.5^{*} \\
(25.6)\end{array}$ & 405 & $\begin{array}{l}66.4^{*} \\
(14.3)\end{array}$ \\
\hline Start-up size (full time equivalent) & 3692 & $\begin{array}{r}2.02 \\
(2.11)\end{array}$ & 494 & $\begin{array}{r}2.18 \\
(2.21)\end{array}$ \\
\hline
\end{tabular}




\begin{tabular}{|c|c|c|c|c|}
\hline Limited company & 3655 & $\begin{array}{r}0.316^{* * *} \\
(0.465)\end{array}$ & 491 & $\begin{array}{r}0.114^{* * * *} \\
(0.318)\end{array}$ \\
\hline $\mathrm{R} \& \mathrm{D}$ & 3692 & $\begin{array}{r}0.252^{* * *} \\
(0.434)\end{array}$ & 494 & $\begin{array}{r}0.085^{* * *} \\
(0.279)\end{array}$ \\
\hline Firm age & 3653 & $\begin{array}{r}2.98 \\
(1.10)\end{array}$ & 491 & $\begin{array}{r}2.92 \\
(1.11)\end{array}$ \\
\hline NTB manufacturing & 3692 & $\begin{array}{r}0.152^{* * *} \\
(0.360)\end{array}$ & 494 & $\begin{array}{r}0.075^{* * *} \\
(0.263)\end{array}$ \\
\hline NTB services & 3692 & $\begin{array}{r}0.226 * * * \\
(0.418)\end{array}$ & 494 & $\begin{array}{r}0.099 * * * \\
(0.299)\end{array}$ \\
\hline Software & 3692 & $\begin{array}{r}0.090 * * * \\
(0.287)\end{array}$ & 494 & $\begin{array}{r}0.015^{* * *} \\
(0.118)\end{array}$ \\
\hline Other manufacturing & 3692 & $\begin{array}{c}0.112^{*} \\
(0.316)\end{array}$ & 494 & $\begin{array}{c}0.085^{*} \\
(0.279)\end{array}$ \\
\hline Knowledge-intensive services & 3692 & $\begin{array}{r}0.060^{* *} \\
(0.238)\end{array}$ & 494 & $\begin{array}{r}0.085^{* *} \\
(0.279)\end{array}$ \\
\hline Other firm-related services & 3692 & $\begin{array}{r}0.043^{* * *} \\
(0.204)\end{array}$ & 494 & $\begin{array}{r}0.083^{* * *} \\
(0.276)\end{array}$ \\
\hline Consumer-related services & 3692 & $\begin{array}{r}0.080 * * * \\
(0.272)\end{array}$ & 494 & $\begin{array}{r}0.194^{* * *} \\
(0.396)\end{array}$ \\
\hline Construction & 3692 & $\begin{array}{r}0.114 * * * \\
(0.318)\end{array}$ & 494 & $\begin{array}{r}0.044^{* * *} \\
(0.206)\end{array}$ \\
\hline Retail & 3692 & $\begin{array}{r}0.121^{* * *} \\
(0.326)\end{array}$ & 494 & $\begin{array}{r}0.320^{* * *} \\
(0.467)\end{array}$ \\
\hline
\end{tabular}

Source: KfW/ZEW Start-Up Panel

Enterprises with more than 22 employees (99\%-quantile of the distribution) have been removed to eliminate extreme values.

${ }^{1}$ Descriptive statistics concerning the regression samples are shown. Observations of the dependent variables which are larger than the 99\%-quantile of the distribution are removed, respectively

2Observations which are smaller than the $1 \%$-quantile of the distribution are removed

Difference between foundation of men and of women: ${ }^{* * *} \mathrm{p}<0.01,{ }^{* *} \mathrm{p}<0.05,{ }^{*} \mathrm{p}<0.1$

\section{Performance Regressions}

The descriptive analysis showed that male and female entrepreneurs are significantly different in several characteristics which are suggested to impact performance. We conducted performance regressions to reveal whether these characteristics really impact performance. This can explain the gender gap in performance.

We estimated two versions of the performance regressions, one with start-up capital and limited company included as right-hand side variables and one without. It turned out that the effect of start-up capital on growth and sales is positive, while it is insignificant with respect to return on sales. The effect of limited company on growth and sales is also positive but is negative with respect to return on sales. However, one should be cautious with interpreting the effects because of the endogenous character of these variables. It is very likely that the amount of start-up capital invested and the choice of legal form are related to the founder's entrepreneurial ability, his/her belief in the future success of the business and the aspired size of the business. We therefore refrain from drawing conclusions regarding the consequences of the lower start-up capital investments by female entrepreneurs for business performance and focus on the results without start-up capital and limited company as regressors (Table 4).

Regarding the human capital variables, we observe that the level of formal education affects all performance indicators positively. The same holds for industry experience. Entrepreneurial and managerial experience increase employment growth and the level of sales, but have a negative impact on return on sales. The fact that women have a lower educational level and have less experience partly explains why their businesses grow slower and have lower sales. Their lower educational level and smaller industry experience also contributes to gender gap in return on sales. However, having less managerial and entrepre- 
neurial experience does not explain the lower profitability of their businesses. Thus, the second part of Hypothesis 1a is not entirely confirmed.

The regressions further indicate that the firms' growth and sales increase with team size. Thus, female's tendency to start-up alone or only with a small team partly explains the lower growth rate and sales volume of her business. By contrast, return on sales is negatively affected by the number of founders. The fact that large teams, just like large amounts of start-up capital, are usually attended by a high sales volume seems to make it difficult for the respective companies to reach a high level of return per sales. The second part of Hypothesis 2 is hence only supported regarding the size and growth related performance measures, but not regarding profitability.

Businesses of founders that were unemployed or not employed before start-up tend to have lower sales than businesses founded out from employment. Moreover, relative employment growth is lower if founders were unemployed. Likewise necessity entrepreneurs fall behind the sales level attained by entrepreneurs whose primary motive is self-determination. Opportunity entrepreneurship has no significant impact on the firm's growth and sales level. Contrary to our expectations, however, it affects return on sales negatively. A possible explanation is that opportunity entrepreneurs offer more innovative products and services than other entrepreneurs. Otherwise their business ideas are unlikely to have acted as the primary pull factor for their start-up decision. It may take some time to develop these products and generate profit with them. Since we are measuring start-up performance over a relatively short period of time positive profitability effects may not show up yet. The negative sign of the R\&D coefficient in the return on sales regression supports this argument. We conclude that differences in entrepreneurial motivation can only explain the lower sales volume of female-founded businesses but not their lower growth rate and their lower profitability. On the contrary, the fact that women are less frequently opportunity entrepreneurs should rather enhance the profitability of their firms, at least in the very first years after start-up. Thus, the second part of Hypothesis 3 is only confirmed with respect to sales performance.

The effect of the industry dummies on performance is highly dependent on the performance indicator considered. Both relative and absolute employment growth tend to be higher in NTB industries and other manufacturing and construction (where female entrepreneurs are underrepresented) than in the retail sector and in consumer-related services (where females are overrepresented). However, the retail sector tends to have larger average sales per start-up than any other industry. NTB services, software and knowledge-intensive services firms perform rather poorly on growth and sales, but tend to have a high profitability. The decomposition analysis will give us more insight into the question to what extent gender differences in industry distribution can explain female underperformance. What we can state up to this point is that females' underrepresentation in the high-tech sector partly explains their underperformance regarding profitability. However, the second part of Hypothesis 4 is not generally supported.

The results for the other explanatory variables are largely as expected. Relative employment growth decreases with firm age, whereas absolute employment growth, sales and return on sales increase with firm age. There is a U-shaped relationship between employment growth and start-up size, where the point in which the relation turns into positive is lower for absolute than for relative employment growth (8 versus 24 full-time employees). The founder's age has a negative effect on growth and profitability. This could indicate that the age of founders rather reflects their degree of risk aversion than their general professional experience.

Even after controlling for the set of explanatory variables, the coefficient of the indicator variable 'female' is still significantly negative with respect to sales and return on sales. 
The poorer performance of female-founded businesses cannot be fully explained by gender differences in the observable characteristics of the founders and firms. By contrast, firms managed by 'mixed teams', that is teams where both sexes are represented, show a similar performance as firms managed by men alone according to the multivariate analysis.

The results of the performance regressions including start-up capital and legal form are given in the appendix (Table A1). They are by and large similar to the results in Table 4. However, the coefficients of variables which are correlated with start-up capital (e.g. human capital, R\&D activity, founder's age) change somewhat when start-up capital and legal form are included as regressors. They decrease in the growth and sales regressions where start-up capital has a positive impact, while they increase in the return on sales regression where start-up capital has a negative impact.

Table 4: Estimation Results - without start-up capital and limited company indicator

\begin{tabular}{|c|c|c|c|c|}
\hline & (1) & (2) & (3) & (4) \\
\hline VARIABLES & $\begin{array}{l}\text { Employment } \\
\text { growth - } \\
\text { relative }\end{array}$ & $\begin{array}{c}\text { Employment } \\
\text { growth }^{1} \text { - } \\
\text { absolute }\end{array}$ & Sales 2008 & $\begin{array}{c}\text { Return on } \\
\text { sales }^{1}\end{array}$ \\
\hline \multicolumn{5}{|l|}{ Founder specific variables } \\
\hline \multirow[t]{2}{*}{ Female } & 0.0118 & 0.00889 & $-0.319 * * *$ & $-0.0405^{* *}$ \\
\hline & $(0.0226)$ & $(0.157)$ & $(0.0784)$ & $(0.0184)$ \\
\hline \multirow[t]{2}{*}{ Mixed Teams } & -0.0348 & -0.189 & -0.0373 & -0.00731 \\
\hline & $(0.0342)$ & $(0.235)$ & $(0.112)$ & $(0.0258)$ \\
\hline \multirow[t]{2}{*}{ Team size } & $0.0864 * * *$ & $0.569 * * *$ & $0.233 * * *$ & $-0.0398 * * *$ \\
\hline & $(0.0110)$ & $(0.0755)$ & $(0.0349)$ & $(0.00770)$ \\
\hline \multirow[t]{2}{*}{ log(Founder's age) } & $-0.0858 * *$ & $-0.517 * *$ & 0.0100 & $-0.0504^{*}$ \\
\hline & $(0.0378)$ & $(0.261)$ & $(0.125)$ & $(0.0290)$ \\
\hline \multirow[t]{2}{*}{ Graduate } & $0.0931^{* * *}$ & $0.667 * * *$ & $0.472 * * *$ & 0.000191 \\
\hline & $(0.0182)$ & $(0.126)$ & $(0.0594)$ & $(0.0138)$ \\
\hline \multirow[t]{2}{*}{ Master craftsman } & $0.0390 * *$ & $0.288 * *$ & $0.171 * * *$ & 0.0153 \\
\hline & $(0.0185)$ & $(0.127)$ & $(0.0611)$ & $(0.0142)$ \\
\hline \multirow[t]{2}{*}{$\log$ (Experience in industry) } & 0.0163 & 0.0207 & $0.236 * * *$ & $0.0256^{* * *}$ \\
\hline & $(0.0121)$ & $(0.0831)$ & $(0.0407)$ & $(0.00940)$ \\
\hline \multirow[t]{2}{*}{ Entrepreneurial experience } & $0.0470 * * *$ & $0.372 * * *$ & $0.242 * * *$ & $-0.0466 * * *$ \\
\hline & $(0.0166)$ & $(0.115)$ & $(0.0539)$ & $(0.0124)$ \\
\hline \multirow[t]{2}{*}{ Managerial experience } & $0.0532 * * *$ & $0.326 * * *$ & $0.203 * * *$ & $-0.0237 *$ \\
\hline & $(0.0163)$ & $(0.113)$ & $(0.0534)$ & $(0.0123)$ \\
\hline \multirow[t]{2}{*}{ Unemployed before } & $-0.0638 * * *$ & -0.222 & $-0.426 * * *$ & 0.0217 \\
\hline & $(0.0218)$ & $(0.151)$ & $(0.0708)$ & $(0.0166)$ \\
\hline \multirow[t]{2}{*}{ Not employed before } & -0.0369 & -0.140 & $-0.541 * * *$ & -0.0258 \\
\hline & $(0.0288)$ & $(0.199)$ & $(0.0963)$ & $(0.0221)$ \\
\hline \multirow[t]{2}{*}{ Motive: opportunity } & 0.0202 & 0.185 & 0.0718 & $-0.0532 * * *$ \\
\hline & $(0.0164)$ & $(0.113)$ & $(0.0538)$ & $(0.0124)$ \\
\hline \multirow[t]{2}{*}{ Motive: necessity } & -0.0320 & -0.163 & $-0.196 * * *$ & -0.00737 \\
\hline & $(0.0208)$ & $(0.144)$ & $(0.0680)$ & $(0.0157)$ \\
\hline \multicolumn{5}{|l|}{ Firm specific variables } \\
\hline \multirow[t]{2}{*}{ Start-up size } & $-0.0933 * * *$ & -0.0706 & & $-0.0332 * * *$ \\
\hline & $(0.00760)$ & $(0.0563)$ & & $(0.00556)$ \\
\hline \multirow[t]{2}{*}{ Start-up size ${ }^{2}$} & $0.00396 * * *$ & $0.00867 * *$ & & $0.00166^{* * *}$ \\
\hline & $(0.000556)$ & (0.00439) & & $(0.000393)$ \\
\hline \multirow[t]{2}{*}{$\mathrm{R} \& \mathrm{D}$} & $0.0669 * * *$ & $0.486 * * *$ & $0.149 * *$ & $-0.0607 * * *$ \\
\hline & $(0.0185)$ & $(0.128)$ & $(0.0604)$ & $(0.0139)$ \\
\hline \multirow[t]{2}{*}{ Firm age } & $-0.0904 * * *$ & $0.114^{* * *}$ & $0.0786 * * *$ & $0.0225 * * *$ \\
\hline & $(0.00633)$ & $(0.0436)$ & $(0.0205)$ & $(0.00473)$ \\
\hline
\end{tabular}




\begin{tabular}{|c|c|c|c|c|}
\hline NTB manufacturing & $\begin{array}{l}0.0887 * * * \\
(0.0272)\end{array}$ & $\begin{array}{l}0.490 * * * \\
(0.188)\end{array}$ & $\begin{array}{l}-0.308^{* * * *} \\
(0.0919)\end{array}$ & $\begin{array}{l}0.0186 \\
(0.0214)\end{array}$ \\
\hline NTB services & $\begin{array}{l}-0.0252 \\
(0.0251)\end{array}$ & $\begin{array}{l}-0.390^{* *} \\
(0.173)\end{array}$ & $\begin{array}{l}-0.725^{* * *} \\
(0.0824)\end{array}$ & $\begin{array}{l}0.119 * * * \\
(0.0191)\end{array}$ \\
\hline Software & $\begin{array}{l}-0.00372 \\
(0.0332)\end{array}$ & $\begin{array}{l}-0.167 \\
(0.229)\end{array}$ & $\begin{array}{l}-0.763^{* * *} \\
(0.107)\end{array}$ & $\begin{array}{l}0.104^{* * *} \\
(0.0242)\end{array}$ \\
\hline Other manufacturing & $\begin{array}{l}0.0886 * * * \\
(0.0283)\end{array}$ & $\begin{array}{l}0.540^{* * *} \\
(0.196)\end{array}$ & $\begin{array}{l}-0.143 \\
(0.0934)\end{array}$ & $\begin{array}{l}-0.0331 \\
(0.0215)\end{array}$ \\
\hline Knowledge-intensive services & $\begin{array}{l}-0.0511 \\
(0.0339)\end{array}$ & $\begin{array}{l}-0.458 * \\
(0.234)\end{array}$ & $\begin{array}{l}-0.695^{* * *} \\
(0.110)\end{array}$ & $\begin{array}{l}0.115^{* * *} \\
(0.0249)\end{array}$ \\
\hline Other firm-related services & $\begin{array}{l}0.103^{* * *} \\
(0.0364)\end{array}$ & $\begin{array}{l}0.518 * * \\
(0.250)\end{array}$ & $\begin{array}{l}-0.464^{* * *} \\
(0.118)\end{array}$ & $\begin{array}{l}0.0517^{*} \\
(0.0276)\end{array}$ \\
\hline Consumer-related services & $\begin{array}{l}0.0158 \\
(0.0286)\end{array}$ & $\begin{array}{l}0.158 \\
(0.198)\end{array}$ & $\begin{array}{l}-0.352 * * * \\
(0.0963)\end{array}$ & $\begin{array}{l}0.0646 * * * \\
(0.0224)\end{array}$ \\
\hline Construction & $\begin{array}{l}0.105^{* * *} \\
(0.0292)\end{array}$ & $\begin{array}{l}0.985^{* * * *} \\
(0.201)\end{array}$ & $\begin{array}{l}-0.248 * * \\
(0.0966)\end{array}$ & $\begin{array}{l}0.0347 \\
(0.0224)\end{array}$ \\
\hline Constant & $\begin{array}{l}0.826^{* * *} \\
(0.131)\end{array}$ & $\begin{array}{l}2.284 * * \\
(0.905) \\
\end{array}$ & $\begin{array}{l}11.14^{* * *} \\
(0.431)\end{array}$ & $\begin{array}{l}0.251 * * \\
(0.100)\end{array}$ \\
\hline Observations & 3916 & 3911 & 3041 & 2331 \\
\hline R-squared & 0.167 & 0.073 & 0.173 & 0.142 \\
\hline $\begin{array}{l}\text { Source: KfW/ZEW Start-Up Panel } \\
\text { Standard errors in parentheses } \\
* * * \mathrm{p}<0.01, * * \mathrm{p}<0.05, * \mathrm{p}<0.1 \\
\text { Enterprises with more than } 22 \text { emp } \\
\text { Observations of the dependent vari } \\
\text { 1Observations which are smaller th }\end{array}$ & $\begin{array}{l}\text { een remo } \\
\text { re larger } t \\
\text { antile of } t\end{array}$ & ution & $\begin{array}{l}\text { ues. } \\
\text { distributic }\end{array}$ & noved, resp. \\
\hline
\end{tabular}

\section{Decomposition Analysis}

The decomposition results based on the performance regressions including start-up capital and legal form suggest that the performance gap is to a large part attributable to the legal form. Given the endogeneity of legal form and start-up capital we report only the results based on the regressions excluding these two variables (Table 5). ${ }^{6}$

Our results reveal that differences in founders' human capital explain a considerable part of the gaps in employment growth and sales. The contribution of the experience variables is larger than the contribution of the variables measuring formal education, thus confirming Hypothesis 1b. However, for the profitability gap holds the reverse. Having less entrepreneurial and managerial experience seems to serve females as an advantage with respect to profitability as indicated by the negative signs of the contribution values in Table 6. This results from the negative impact of these types of experience on return on sales according to the performance regressions. Only women's smaller industry experience contributes to explain their weaker profitability performance. Altogether the contribution of the experience variables to the profitability gap is negative.

Differences in team size also contribute considerably to performance gaps in growth and size. The fact that females are part of smaller start-up teams explains about $30 \%$ of the female underperformance in employment growth and $12 \%$ of the gap in sales. By contrast, it adds to the gap in return on sales because a smaller team size should enhance profitability according to the performance regressions.

Differences in previous employment status and entrepreneurial motivation also contribute to the gap in employment growth and sales. The fact that females often start-up from

\footnotetext{
${ }^{6}$ The decomposition results including start-up capital and legal form are given in the appendix (Table A2).
} 
unemployment and are driven rather by necessity than by opportunity is another reason why their firms have lower sales and grow slower on average. However, differences in motivation enlarge the gap in profitability because opportunity entrepreneurs attain significantly lower returns on sales than other entrepreneurs. The same applies to differences in R\&D activity. This is in line with the argument that there is a link between opportunity entrepreneurship and innovative activity, and that innovative firms are more likely to have negative profits shortly after start-up. Thus, on the one hand, women's retention from R\&D serves them as an advantage with respect to profitability in the first months and years after start-up. On the other hand, it contributes to the smaller growth rates and lower sales levels of their firms.

The decomposition results reveal further that gender differences in industry distribution contribute to explain female underperformance with respect to all performance indicators except sales. Their underrepresentation in the NTB industries contributes to their lower profitability. Altogether, differences in industry distribution explain about $17-20 \%$ of the gap in employment growth and $30 \%$ of the gap in return on sales. By contrast, they enlarge the gap in sales by $18 \%$. This is due to the higher-than-average sales in the retail sector in which women are overrepresented.

The differences in the observed characteristics can explain the gender gap in relative and absolute employment growth, where they account for $123 \%$ resp. $105 \%$ of the gap (bottom line of Table 5). Remember that the two growth measures were the only performance indicators which were no longer significantly influenced by the founder's gender after controlling for the explanatory variables. The share of over $100 \%$ indicates that given the characteristics of female founders and their firms and assuming that the coefficient estimates from the pooled regression adequately describe the behaviour of female entrepreneurs, female-founded businesses would be expected to exhibit even smaller employment growth than they actually do. In other words, taking into account that female founders start up with smaller teams, are less educated, are less experienced, often start-up from necessity, and are overrepresented in the low-tech industry, it is in fact surprising that their businesses grow as fast as they do. As to the sales gap, only $40 \%$ of the observed gender differences in start-up performance can be explained by the gender differences in explanatory variables. The explained share is even negative in the case of return on sales (-17\%), indicating that female-founded businesses would be expected to exhibit larger and not smaller returns on sales than male-founded ones. This is because starting-up in smaller teams, being less experienced in entrepreneurial and managerial tasks, and not being an opportunity entrepreneur is in fact favourable to profitability in the first years of business operations according to our results. Taking all founder and firm specific characteristics together, female entrepreneurs should actually have the edge over their male counterparts in terms of profitability. 
Table 5: Decomposition of male / female performance gaps - without start-up capital and limited company indicator

\begin{tabular}{cc}
$\begin{array}{c}\text { Employment } \\
\text { growth - } \\
\text { relative }\end{array}$ & $\begin{array}{c}\text { Employment } \\
\text { growth - } \\
\text { absolute }\end{array}$ \\
\hline
\end{tabular}

VARIABLES

Founder specific variables

Team size

$\log$ (Founder's age)

Graduate

Master craftsman

$\log ($ experience in industry)

Entrepreneurial experience

Managerial experience

Unemployed before

Not employed before

Motive: opportunity

Motive: necessity

Firm specific variables

Start-up size

Start-up size ${ }^{2}$

$\mathrm{R} \& \mathrm{D}$

Firm age

NTB manufacturing

NTB services

Software

Other manufacturing

Knowledge-intensive services

Other firm-related services

Consumer-related services

Construction
(1)

(2) absolute

(3)

(4)

3)

Return on
Sales

\begin{tabular}{|c|c|c|c|}
\hline 0,0192 & 0,1148 & 0,0571 & $-0,0063$ \\
\hline $30,8 \%$ & $27,3 \%$ & $12,1 \%$ & $-21,0 \%$ \\
\hline 0,0025 & 0,0157 & 0,0005 & 0,0018 \\
\hline $4,0 \%$ & $3,7 \%$ & $0,1 \%$ & $6,0 \%$ \\
\hline 0,0065 & 0,0443 & 0,0206 & 0,0001 \\
\hline $10,4 \%$ & $10,5 \%$ & $4,4 \%$ & $0,2 \%$ \\
\hline 0,0027 & 0,0183 & 0,0139 & 0,0013 \\
\hline $4,4 \%$ & $4,3 \%$ & $2,9 \%$ & $4,3 \%$ \\
\hline 0,0036 & 0,0044 & 0,0566 & 0,0042 \\
\hline $5,8 \%$ & $1,0 \%$ & $12,0 \%$ & $14,0 \%$ \\
\hline 0,0050 & 0,0447 & 0,0309 & $-0,0055$ \\
\hline $8,0 \%$ & $10,6 \%$ & $6,5 \%$ & $-18,1 \%$ \\
\hline 0,0036 & 0,0222 & 0,0136 & $-0,0019$ \\
\hline $5,8 \%$ & $5,3 \%$ & $2,9 \%$ & $-6,2 \%$ \\
\hline 0,0030 & 0,0079 & 0,0260 & $-0,0017$ \\
\hline $4,8 \%$ & $1,9 \%$ & $5,5 \%$ & $-5,6 \%$ \\
\hline 0,0006 & $-0,0008$ & 0,0052 & 0,0001 \\
\hline $1,0 \%$ & $-0,2 \%$ & $1,1 \%$ & $0,4 \%$ \\
\hline 0,0012 & 0,0104 & 0,0056 & $-0,0029$ \\
\hline $1,9 \%$ & $2,5 \%$ & $1,2 \%$ & $-9,7 \%$ \\
\hline 0,0023 & 0,0110 & 0,0152 & 0,0008 \\
\hline $3,6 \%$ & $2,6 \%$ & $3,2 \%$ & $2,5 \%$ \\
\hline 0,0129 & 0,0090 & & 0,0048 \\
\hline $20,6 \%$ & $2,1 \%$ & & $15,9 \%$ \\
\hline$-0,0018$ & $-0,0066$ & & 0,0007 \\
\hline$-2,8 \%$ & $-1,6 \%$ & & $2,2 \%$ \\
\hline 0,0088 & 0,0675 & 0,0257 & $-0,0098$ \\
\hline $14,0 \%$ & $16,0 \%$ & $5,4 \%$ & $-32,4 \%$ \\
\hline$-0,0058$ & 0,0065 & 0,0012 & 0,0002 \\
\hline$-9,3 \%$ & $1,5 \%$ & $0,3 \%$ & $0,6 \%$ \\
\hline 0,0068 & 0,0443 & $-0,0273$ & 0,0012 \\
\hline $10,9 \%$ & $10,5 \%$ & $-5,8 \%$ & $4,0 \%$ \\
\hline$-0,0030$ & $-0,0506$ & $-0,0805$ & 0,0123 \\
\hline$-4,8 \%$ & $-12,0 \%$ & $-17,0 \%$ & $40,9 \%$ \\
\hline$-0,0004$ & $-0,0181$ & $-0,0574$ & 0,0091 \\
\hline$-0,6 \%$ & $-4,3 \%$ & $-12,1 \%$ & $30,1 \%$ \\
\hline 0,0029 & 0,0189 & $-0,0059$ & $-0,0017$ \\
\hline $4,6 \%$ & $4,5 \%$ & $-1,3 \%$ & $-5,7 \%$ \\
\hline 0,0020 & 0,0192 & 0,0382 & $-0,0063$ \\
\hline $3,2 \%$ & $4,5 \%$ & $8,1 \%$ & $-20,9 \%$ \\
\hline$-0,0031$ & $-0,0096$ & 0,0208 & $-0,0015$ \\
\hline$-5,0 \%$ & $-2,3 \%$ & $4,4 \%$ & $-4,8 \%$ \\
\hline$-0,0007$ & $-0,0070$ & 0,0434 & $-0,0072$ \\
\hline$-1,1 \%$ & $-1,7 \%$ & $9,2 \%$ & $-23,8 \%$ \\
\hline $\mathbf{0 , 0 0 7 7}$ & 0,0752 & $-0,0141$ & 0,0031 \\
\hline
\end{tabular}




\begin{tabular}{lcccr} 
& $\mathbf{1 2 , 4 \%}$ & $\mathbf{1 7 , 9 \%}$ & $\mathbf{- 3 , 0 \%}$ & $10,1 \%$ \\
\hline Sum of differences & 0,0767 & 0,4416 & 0,1892 & $-0,0051$ \\
\hline $\begin{array}{l}\text { Difference in dependent variable (per- } \\
\text { formance gap) }\end{array}$ & 0,0625 & 0,4210 & 0,4736 & 0,0302 \\
\hline Overall contribution to performance gap & $122,7 \%$ & $104,9 \%$ & $39,9 \%$ & $-17,0 \%$ \\
\hline
\end{tabular}

Source: KfW/ZEW Start-Up Panel

Significant effects in bold

\section{Conclusions}

Our analysis revealed that gender differences in human capital, team size, entrepreneurial motivation and industry distribution can explain parts of female entrepreneurial underperformance. The importance of these differences depends largely on the performance indicator considered. Growth and size differences are determined by other characteristics than profitability. When analyzing the causes of female underperformance, it is therefore important to differentiate between these performance measures.

We found that female-founded firms perform worse for all three indicators. At the same time, there are significant gender differences in many characteristics that are supposed to impact start-up performance. Compared to male entrepreneurs, female entrepreneurs have a lower level of formal education, less professional experience, are part of smaller start-up teams, are more often driven by necessity, and are overrepresented in the retail and service industries and in lower-tech industries in general. However, these gender differences do not always contribute to female underperformance. For example, females are overrepresented in the retail sector which is characterized by higher-than-average sales. In addition, starting with a smaller team and being driven by necessity rather than by opportunity seems to have a positive impact on profitability. At least this holds for the relatively short period after foundation over which we measure performance here.

Our results do not provide clear evidence for either liberal or social feminist theory. As to liberal feminist theory, we find that gender differences in founders' resources (human capital, business partners) partly explain the performance gaps. But there is also evidence that the profitability gap becomes even larger when accounting for gender differences in specific resources like the number of team partners and entrepreneurial experience. As to social feminist theory, the gap in return on sales itself speaks against the theory's implication that female entrepreneurs are as efficient managers as male entrepreneurs. We do not find evidence for gender differences in profit orientation but find that female entrepreneurs are less growth-oriented.

Data limitations prevent us from a concluding evaluation of the two theories. We lack information on the time resources available to male and female entrepreneurs. We neither observe the hours worked in the business nor do we have valid information on the founders' family commitments. Thus we are unable to test the hypothesis that female entrepreneurs underperform because they are more strained by domestic responsibilities. We suppose that founders that are heavily strained by family commitments would tend to assign to the motive of self-determination, but we found no gender differences with respect to this motive. Moreover, we observe business goals and entrepreneurial motivation, but we lack information on personal traits like risk attitude and self-efficacy which may also affect entrepreneurial performance. Finally, we observe performance only over a relatively short period after foundation. In particular innovative, opportunity-based start-ups may exhibit rather low sales and profits during that time. This may bias the results of the analysis of performance differences by gender. It is interesting to see how the results change when the observation period lengthens as more waves of the KfW/ZEW Start-up Panel become available. 


\section{References}

Blinder, A.S. (1973), Wage Discrimination; Reduced Form and Structural Estimates, Journal of Human Resources, 8, 436-455.

Boden, R. J. (1999), Flexible Working Hours, Family Responsibilities, and Female SelfEmployment, American Journal of Economics and Sociology, 58, 1, 71-83.

Boden, R. J. and Nucci, A. R. (2000), On the Survival Prospects of Men's and Women's New Business Ventures, Journal of Business Venturing, 15, 4, 347-362.

Carter, N. M., Williams, M. and Reynolds, P. D. (1997), Discontinuance Among New Firms in Retail: The Influence of Initial Resources, Strategy, and Gender, Journal of Business Venturing, 12, 125-145.

Carter, S. and Rosa, P. (1998), The Financing of Male- and Female-Owned Businesses, Entrepreneurship and Regional Development, 10, 3, 225-241.

Chaganti, R. and Parasuraman, S. (1996), A Study of the Impacts of Gender on Business Performance and Management Patterns in Small Businesses, Entrepreneurship Theory and Practice, 21, 2, 73-75.

Cliff, J. E. (1998), Does One Size Fit All? Exploring the Relationship Between Attitudes Towards Growth, Gender, and Business Size, Journal of Business Venturing, 13, 523-542.

Cole, R. A. and Wolken, J. D. (1995), Financial Services Used by Small Businesses: Evidence from the 1993 National Survey of Small Business Finances, Federal Reserve Bulletin, July 1995, 629-667.

Coleman, S. (1999), Access to Capital and Terms of Credit: A Comparison of Men- and WomenOwned Small Businesses, Journal of Small Business Management, 38, 3, 37-52.

Coleman, S. (2000), Sources of Small Business Capital: A Comparison of Men- and WomenOwned Small Businesses, The Journal of Applied Management and Entrepreneurship, 4, 2, 138-152.

Cuba, R., Decenzo, D. and Anish, A. (1983), Management Practices of Successful Female Business Owners, American Journal of Small Business, 8, 2, 40-45.

Döbler, T. (1998), Frauen als Unternehmerinnen: Erfolgspotentiale weiblicher Selbständiger, DUV, Wiesbaden.

Doutriaux, J. (1992), Emerging High-Tech Firms: How Durable Are Their Comparative Start-up Advantages? Journal of Business Venturing, 7, 4, 303-322.

Du Rietz, A. and Henrekson, M. (2000), Testing the Female Underperformance Hypothesis, Small Business Economics, 14, 1-10.

Fabowale, L., Orser, B., and Riding, A. (1995), Gender, Structural Factors, and Credit Terms Between Canadian Small Businesses and Financial Institutions, Entrepreneurship Theory and Practice, 19, 41-65.

Fairly, R. W. (2005), An Extension of the Blinder-Oaxaca Decomposition Technique to Logit and Probit Models, Journal of Economic and Social Measurement, 30, 305-316.

Fairlie, R. W. and Robb, A. M. (2009), Gender Differences in Business Performance: Evidence from the Characteristics of Business Owners Survey, Small Business Economics, 33, 375395.

Fasci, M. and Valdez, J. (1998), A Performance Contrast of Male and Female Owned Small Accounting Practices, Journal of Small Business Management, 36, 3, 1-7.

Kalleberg, A. L. and Leicht, K. T. (1991), Gender and Organisational Performance: Determinants of Small Business Survival and Success, Academy of Management Journal, 34, 1, 136-161.

Fischer, E. M., Reuber, A. R. and Dyke, L. S. (1993), A Theoretical Overview and Extension of Research on Sex, Gender, and Entrepreneurship, Journal of Business Venturing, 8, 151-168.

Furdas, M. and Kohn, K. (2010), What's the Difference?! Gender, Personality, and the Propensity to Start a Business, IZA Discussion Paper No. 4778. 
Gatewood, E. J., Brush, C. G., Carter, N. M., Greene, P. G. and Hart, M. M. (2009), Diana: A Symbol of Women Entrepreneurs' Hunt for Knowledge, Money, and the Rewards of Entrepreneurship, Small Business Economics, 32, 129-144.

Goffee, R. and Scase, R. (1985), Women in Charge: The Experiences of Female Entrepreneurs, London, Allen and Unwin.

Hundley, G. (2001), Why Women Earn Less Than Men in Self-Employment, Journal of Labor Research, 22, 4, 817-829.

Jones, F. (1983), On Decomposing the Wage Gap: A Critical Comment on Blinder’s Method, Journal of Human Resources, 18(1), 126-130.

Kalleberg, A. L. and Leicht, K. T. (1991), Gender and Organizational Performance: Determinants of Small Business Survival and Success, Academy of Management Journal, 34, 1, 136-161.

Liou, N. and Aldrich, H. E. (1995), Women Entrepreneurs: Is there a Gender-Based Relational Competence? Presented at the 1995 American Sociological Association Meeting, Washington, DC.

Loscocco, K. A., Robinson, J., Hall, R. H. and Allen, J. K. (1991), Gender and Small Business Success: An Inquiry into Women’s Relative Disadvantage, Social Forces, 70, 1, 65-85.

Minniti, M., Allen, I. E. and Langowitz, N. (2006), Global Entrepreneurship Monitor. 2005 Report on Women Entrepreneurship, Babson College und London Business School.

Müller, K. (2010), Academic Spin-off's Transfer Speed-Analyzing the Time from Leaving University to Venture, Research Policy 39 (2), 189-199.

Muravyev, A., Schäfer, D. and Talavera, O. (2007), Bankkredite für Unternehmerinnen: Geringe Benachteiligung in entwickelten Finanzsystemen, DIW Wochenbericht Nr. 34/2007, Deutsches Institut für Wirtschaftsforschung, Berlin.

Oaxaca, R. (1973), Male-female Wage Differentials in Urban Labor Markets, International Economic Review, 14, 693-709.

Oaxaca, R. and M. Ransom (1994), On Discrimination and the Decomposition of Wage Differentials, Journal of Econometrics, 61, 5-21.

OECD (1998), Women Entrepreneurs in Small and Medium Enterprises, OECD Conference Paris 1997.

Orser, B. J., Riding, A. L. and Manley, K. (2006), Women Entrepreneurs and Financial Capital, Entrepreneurship Theory and Practice, 30, 5, 643-665.

Robb, A. and Watson, J. (2010), Comparing the Performance of Female- and Male-Controlled SMEs: Evidence from Australia and the U.S., mimeo.

Rosa, P., Carter, S. and Hamilton, D. (1996), Gender as a Determinant of Small Business Performance: Insights from a British Study, Small Business Economics, 8, 463-478.

Scott, C. E. (1986), Why More Women are Becoming Entrepreneurs, Journal of Small Business Management, 24, 4, 37-44.

Sexton, D. and Bowman-Upton, N. (1990), Female and Male Entrepreneurs: Psychological Characteristics and Their Role in Gender Discrimination, Journal of Business Venturing, 5, 1, 29-36.

Swinney, J. L., Runyan, R. C. and Huddleston, P. (2006), Differences in Reported Firm Performance by Gender: Does Industry Matter?, Journal of Developmental Entrepreneurship, 11, 2, 99-115.

Teach, R. D., Tarpley, F. A. and Schwartz, R. G. (1986), Software Venture Teams, in Ronstadt, R., Hornaday, John A., Peterson, R. and Vesper, K. H.: Frontiers of Entrepreneurship Research, 1986 - Proceedings of the 1986 Babson College Entrepreneurship Research Conference, Wellesley, MA, 546-562.

Verheul, I. and Thurik, A. R. (2001), Start-up Capital: Differences Between Male and Female Entrepreneurs: Does Gender Matter?, Small Business Economics, 16, 4, 329-345.

Watson, J. (2001), Examining the Impact on Performance of Demographic Differences Between Male and Female Controlled SMEs, Small Enterprise Research: The Journal of SEAANZ, 9, 2, 55-70. 
Watson, J. (2002), Comparing the Performance of Male- and Female-controlled Businesses: Relating Outputs to Inputs, Entrepreneurship Theory and Practice, 26, 3, 91-100.

\section{Appendix}

Table A1: Estimation Results - including start-up capital and limited company indicator

\begin{tabular}{|c|c|c|c|c|}
\hline \multirow[b]{2}{*}{ VARIABLES } & (1a) & (2a) & (3a) & (4a) \\
\hline & $\begin{array}{c}\text { Employment } \\
\text { growth - relati- } \\
\text { ve } \\
\end{array}$ & $\begin{array}{c}\text { Employment } \\
\text { growth }^{1} \text { - abso- } \\
\text { lute } \\
\end{array}$ & Sales 2008 & $\begin{array}{c}\text { Return on } \\
\text { sales }^{1}\end{array}$ \\
\hline \multicolumn{5}{|l|}{ Founder specific variables } \\
\hline \multirow[t]{2}{*}{ Female } & 0.0150 & 0.151 & $-0.335 * * *$ & $-0.0715^{* * *}$ \\
\hline & $(0.0238)$ & $(0.165)$ & $(0.0738)$ & $(0.0188)$ \\
\hline \multirow[t]{2}{*}{ Mixed Teams } & $-0.0677 *$ & $-0.441^{*}$ & -0.132 & -0.00438 \\
\hline & $(0.0357)$ & $(0.246)$ & $(0.106)$ & $(0.0260)$ \\
\hline \multirow[t]{2}{*}{ Team size } & $0.0604 * * *$ & $0.394 * * *$ & $0.108 * * *$ & $-0.0185^{* *}$ \\
\hline & $(0.0119)$ & $(0.0814)$ & $(0.0337)$ & $(0.00829)$ \\
\hline \multirow[t]{2}{*}{$\log$ (Founder's age) } & $-0.139 * * *$ & $-1.036 * * *$ & $-0.282 * *$ & -0.00935 \\
\hline & $(0.0394)$ & $(0.271)$ & $(0.117)$ & $(0.0296)$ \\
\hline \multirow[t]{2}{*}{ Graduate } & $0.0508 * * *$ & $0.334^{* *}$ & $0.230 * * *$ & $0.0347^{* *}$ \\
\hline & $(0.0191)$ & $(0.131)$ & $(0.0561)$ & $(0.0141)$ \\
\hline \multirow[t]{2}{*}{ Master craftsman } & 0.0282 & 0.144 & 0.0765 & 0.0214 \\
\hline & $(0.0192)$ & $(0.132)$ & $(0.0570)$ & $(0.0144)$ \\
\hline \multirow[t]{2}{*}{$\log ($ Experience in industry) } & 0.00286 & 0.0331 & $0.151^{* * *}$ & $0.0253^{* * *}$ \\
\hline & $(0.0126)$ & $(0.0867)$ & $(0.0383)$ & $(0.00957)$ \\
\hline \multirow[t]{2}{*}{ Entrepreneurial experience } & 0.0230 & $0.200 *$ & $0.136 * * *$ & $-0.0295 * *$ \\
\hline & $(0.0173)$ & $(0.119)$ & $(0.0503)$ & $(0.0126)$ \\
\hline \multirow[t]{2}{*}{ Managagerial experience } & $0.0485 * * *$ & $0.329 * * *$ & $0.139 * * *$ & -0.0173 \\
\hline & $(0.0170)$ & $(0.117)$ & $(0.0499)$ & $(0.0124)$ \\
\hline \multirow[t]{2}{*}{ Unemployed before } & $-0.0392 *$ & 0.00984 & $-0.288 * * *$ & 0.00846 \\
\hline & $(0.0224)$ & $(0.154)$ & $(0.0657)$ & $(0.0167)$ \\
\hline \multirow[t]{2}{*}{ Not employed before } & -0.00943 & 0.0607 & $-0.393 * * *$ & $-0.0434^{*}$ \\
\hline & $(0.0305)$ & $(0.210)$ & $(0.0904)$ & $(0.0225)$ \\
\hline \multirow[t]{2}{*}{ Motive: opportunity } & -0.00823 & 0.00893 & -0.0294 & $-0.0312^{* *}$ \\
\hline & $(0.0170)$ & $(0.117)$ & $(0.0500)$ & $(0.0126)$ \\
\hline \multirow[t]{2}{*}{ Motive: necessity } & -0.0103 & -0.0922 & -0.0407 & -0.0123 \\
\hline & $(0.0214)$ & $(0.147)$ & $(0.0628)$ & $(0.0156)$ \\
\hline \multicolumn{5}{|l|}{ Firm specific variables } \\
\hline \multirow[t]{2}{*}{ Start-up size (fte) } & $-0.132 * * *$ & $-0.346 * * *$ & & $-0.0186 * * *$ \\
\hline & $(0.00828)$ & $(0.0624)$ & & $(0.00587)$ \\
\hline \multirow[t]{2}{*}{ Start-up size (fte) ${ }^{2}$} & $0.00540 * * *$ & $0.0211^{* * *}$ & & $0.00115^{* * *}$ \\
\hline & $(0.000608)$ & $(0.00504)$ & & $(0.000414)$ \\
\hline \multirow[t]{2}{*}{$\log ($ Start-up capital) } & -0.0239 & -0.412 & $0.690 * * *$ & -0.0351 \\
\hline & $(0.0571)$ & $(0.399)$ & $(0.171)$ & $(0.0429)$ \\
\hline \multirow[t]{2}{*}{$\log ($ Start-up capital)² } & $0.00474 *$ & $0.0415 * *$ & $-0.0141^{*}$ & 0.000608 \\
\hline & $(0.00274)$ & $(0.0192)$ & $(0.00819)$ & $(0.00206)$ \\
\hline \multirow[t]{2}{*}{ Limited company } & $0.201 * * *$ & $1.330 * * *$ & $0.740 * * *$ & $-0.164 * * *$ \\
\hline & $(0.0195)$ & $(0.135)$ & $(0.0564)$ & $(0.0141)$ \\
\hline \multirow[t]{2}{*}{ R\&D } & $0.0327 *$ & $0.246^{*}$ & -0.0282 & $-0.0257^{*}$ \\
\hline & $(0.0192)$ & $(0.132)$ & $(0.0563)$ & $(0.0141)$ \\
\hline \multirow[t]{2}{*}{ Firm age } & $-0.0833 * * *$ & $0.167 * * *$ & $0.112 * * *$ & $0.0159 * * *$ \\
\hline & $(0.00659)$ & $(0.0452)$ & $(0.0192)$ & $(0.00482)$ \\
\hline NTB manufacturing & $0.0467 *$ & $0.322 *$ & $-0.378 * * *$ & 0.0316 \\
\hline
\end{tabular}




\begin{tabular}{lllll} 
& $(0.0283)$ & $(0.195)$ & $(0.0851)$ & $(0.0215)$ \\
NTB services & -0.00110 & -0.181 & $-0.425^{* * *}$ & $0.106^{* * *}$ \\
Software & $(0.0263)$ & $(0.180)$ & $(0.0773)$ & $(0.0193)$ \\
& 0.000112 & -0.120 & $-0.498^{* * *}$ & $0.105^{* * *}$ \\
Other manufacturing & $(0.0342)$ & $(0.234)$ & $(0.0999)$ & $(0.0246)$ \\
& $0.0498^{*}$ & $0.378^{*}$ & $-0.274^{* * *}$ & -0.0261 \\
Knowledge-int. services & $(0.0297)$ & $(0.205)$ & $(0.0873)$ & $(0.0218)$ \\
& -0.0371 & -0.322 & $-0.466^{* * *}$ & $0.122^{* * *}$ \\
Other firm-related services & $(0.0351)$ & $(0.241)$ & $(0.103)$ & $(0.0251)$ \\
& $0.0852^{* *}$ & $0.479^{*}$ & $-0.347^{* * *}$ & 0.0400 \\
Consumer-related services & $(0.0385)$ & $(0.264)$ & $(0.112)$ & $(0.0281)$ \\
& 0.0118 & 0.144 & $-0.430^{* * *}$ & $0.0565^{* *}$ \\
Construction & $(0.0296)$ & $(0.204)$ & $(0.0890)$ & $(0.0226)$ \\
Constant & $0.116 * * *$ & $1.020^{* * *}$ & -0.103 & 0.0247 \\
& $(0.0306)$ & $(0.210)$ & $(0.0898)$ & $(0.0225)$ \\
\hline Observations & $0.830^{* * *}$ & $4.148^{*}$ & $6.674 * * *$ & $0.404^{*}$ \\
R-squared & $(0.318)$ & $(2.212)$ & $(0.950)$ & $(0.242)$ \\
\hline
\end{tabular}

Source: KfW/ZEW Start-Up Panel

Standard errors in parentheses

$* * * \mathrm{p}<0.01, * * \mathrm{p}<0.05, * \mathrm{p}<0.1$

Enterprises with more than 25 employees are removed

Observations of the dependent variables which are larger than the $99 \%$-quantile of the distribution are removed, resp.

${ }^{1}$ Observations which are smaller than the $1 \%$-quantile of the distribution are removed

Table A2: Decomposition of male / female difference in performance - including start-up capital and limited company indicator

(1a) (2a)

Employment Employment

growth - relati- growth - abso-

VARIABLES

ve

lute

Founder specific variables

Team size

0,0129

$18,5 \%$

$\log$ (Founder’s Age)

0,0042

$6,1 \%$

Graduate

$\mathbf{0 , 0 0 2 5}$

$3,6 \%$

Master craftsman

0,0018

$2,6 \%$

$\log$ (experience in industry)

Entreprepreneurial experience

Managagerial experience

0,0013

$1,8 \%$

0,0018

$2,6 \%$

0,0041

$5,9 \%$

Unemployed before

0,0018

$2,5 \%$

Not employed before

0,0001

$0,1 \%$

Motive: opportunity

$-0,0002$

$-0,3 \%$

Motive: necessity
0,0011

$1,5 \%$
(3)

(4)

Sales $2009 \quad$ Return on sales 
Firm specific variables

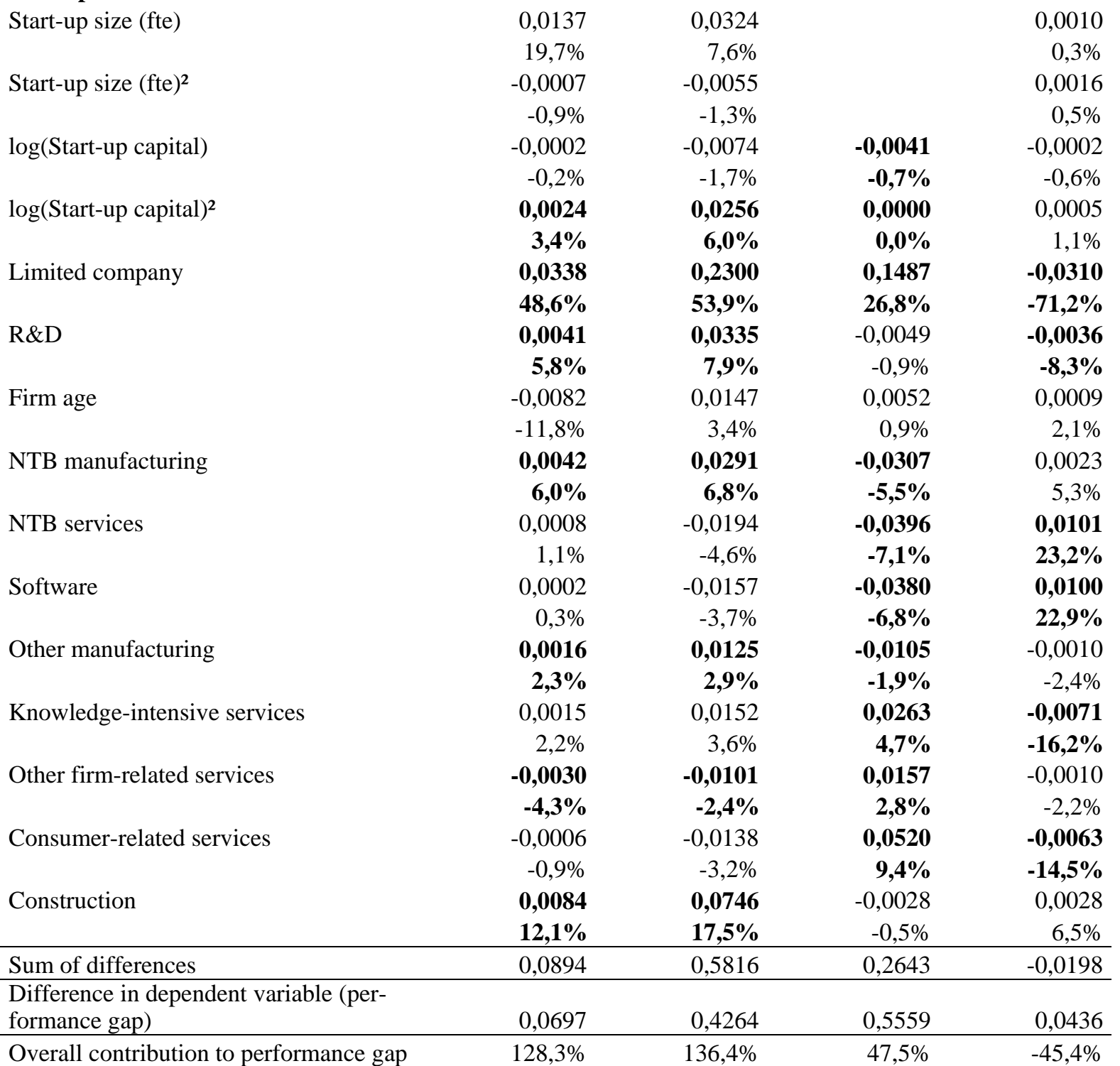

Source: KfW/ZEW Start-Up Panel

Significant effects in bold 